\title{
Peran stakeholders dalam membangun identitas Purwakarta yang berwawasan nilai budaya lokal
}

\author{
Susie Perbawasari ${ }^{1}$, Susanne Dida ${ }^{2}$, dan Aat Ruchiat Nugraha ${ }^{3}$ \\ ${ }^{1,2,3}$ Universitas Padjadjaran
}

\begin{abstract}
ABSTRAK
Proses pembangunan mental dan infrastruktur di suatu daerah menjadi kekuatan utama dalam usaha meningkatkan kesejahteraan masyarakat. Purwakarta sebagai pusat kawasan Badan Koordinasi Pemerintahan dan Pembangunan Wilayah II Jawa Barat yang meliputi Karawang, Subang dan Bekasi memiliki posisi yang strategis dalam proses pengembangan wilayahnya dalam upaya mewujudkan pembangunan yang merata bagi masyarakat. Purwakarta yang termasuk sebagai wilayah penyangga pembangunan industri metropolitan sangat rentan terpengaruh oleh arus perubahan budaya dari wilayah sekitarnya, terutama yang berasal dari Jakarta, Bekasi, dan Karawang. Dalam upaya menjaga nilai-nilai kedaerahan di Purwakarta, maka proses pembangunan yang dilakukan di kabupaten Purwakarta dengan melaksanakan pembangunan yang berwawasan pada nilai-nilai budaya lokal yang dipadukan dengan perkembangan ilmu pengetahuan dan teknologi. Nilainilai budaya lokal tersebut diimplementasi pada berbagai sektor pembangunan di Purwakarta terutama yang berkaitan dengan layanan publik seperti bidang kesehatan, pendidikan, kesejahteraan sosial, pariwisata, dan infrastruktur. Penelitian ini bertujuan untuk mengetahui dan menjelaskan mengenai peran stakeholders dalam membangun daerah Purwakarta yang berwawasan nilai budaya Sunda yang dapat menjadi identitas daerah. Penelitian ini menggunakan metode deskriptif kualitatif dengan teknik pengumpulan data melalui observasi, wawancara, focus group discussion, dan studi pustaka. Hasil penelitian menunjukkan bahwa peran pemerintah kabupaten Purwakarta sangat dominan dalam mengembangkan proses pembangunan yang berwawasan nilai budaya Sunda terutama semenjak kepemimpinan Bupati Dedi Mulyadi. Akhirnya, adanya sinergis antar stakeholders di Purwakarta telah memberikan dampak yang baik bagi keterkenalan pembangunan Purwakarta sebagai salah satu kabupaten yang memiliki identitas dan menjadi tujuan destinasi wisata baru di Jawa Barat.
\end{abstract}

Kata-kata Kunci: Kabupaten Purwakarta; stakeholders; identitas; budaya Sunda; nilai-nilai

\section{The role of stakeholders in building a Purwakarta identity that is local cultural value}

\begin{abstract}
The process of mental development and infrastructure in an area the prime force in efforts to improve people's welfare. Purwakarta as the regional center of the Government and Development Coordinating Board for Region II West Java which includes Karawang, Subang and Bekasi have a strategic position in the process of developing their region to realize equitable development for the community. Purwakarta which included as a buffer zone for the development of the city industry is very vulnerable to being influenced by the flow of cultural change from the surrounding area, especially those from Jakarta, Bekasi, and Karawang. For safeguard area values in Purwakarta, the development process is carried out in Purwakarta district by implementing development that is insightful to local cultural values combined with the development of science and technology. These local cultural values achieved in various development sectors in Purwakarta, especially those related to public services such as health, education, social welfare, tourism, and infrastructure. This research aims to find out and explain the role of stakeholders in developing the Purwakarta area that has Sundanese cultural values that can be an identity of the region. The results showed that the part of the Purwakarta regency government was very dominant in developing a development process that was insightful to the value of Sundanese culture especially since the leadership of Regent Dedi Mulyadi. Finally, the synergy between stakeholders in Purwakarta has had a good impact on the development of Purwakarta as one of the districts that have an identity and is a new tourist destination in West Java.
\end{abstract}

Keywords: Purwakarta regency; stakeholders; identity; Sundanese culture; values

Korespondensi: Dr. Susie Perbawasari, M.Si. Universitas Padjadjaran. J1. Raya Bandung-Sumedang Km.21. Email: susie.perbawasari@unpad.ac.id 


\section{PENDAHULUAN}

Identitas suatu bangsa menjadi penting untuk membedakan satu bangsa dengan bangsa lainnya. Pembentukan identitas dapat dilakukan melalui pelestarian budaya yang diterapkan melalui proses pembangunan fisik maupun mental. Menurut Aiysiyah \& Dewi (2011) identitas melekat pada nilai budaya yang terdapat pada suatu kelompok yang bersifat kolektif. Maka, keberhasilan suatu pembangunan agar menjadi identitas suatu daerah diperlukan kerjasama antar sektor kepentingan untuk mewujudkannya.

Pembangunan yang berkeadilan dan merata sudah saatnya dapat tercapai melalui perpaduan antara ilmu pengetahuan teknologi dengan budaya yang akan menghasilkan daya saing suatu bangsa. Gagasan pembangunan yang berwawasan budaya merupakan bagian dari keunggulan yang dapat dipromosikan ke mancanegara sebagai bangsa yang beradab dan dapat dijadikan sebagai identias nation/local branding suatu bangsa. Hal ini sebagaimana yang diungkapkan oleh Razi bahwa pembentukan identitas biasanya disertai dengan persepsi terhadap realitas beserta simbolitasnya yang dapat memberikan kesadaran bahwa ada tanggung jawab kolektif terhadap nasib komunitas, dan yang paling penting dari keberhasilan pembangunan di suatu bangsa adalah adanya peran aktif dari semua lapisan masyarakat untuk dapat mensukseskannya (Razi, 2011).

Purwakarta sebagai sebuah kabupaten di Jawa Barat, selama 10 tahun terakhir ini yaitu sejak 2008-2018 di era kepemimpinan Bupati Dedi Mulyadi menggalakan pola pembangunan mental dan fisik yang berlandaskan nilai-nilai budaya lokal, terutama budaya Sunda. Selama ini kabupaten Purwakarta dianggap sebagai kota untuk tujuan bagi orang-orang pensiun saja dikarenakan sepi dari geliat kehidupan warga masyarakat Purwakarta, khususnya yang terkait dengan sektor peningkatan perekonomian daerah yang ditandai dengan tidak adanya hiruk pikuk kendaraan dan lalu lalang manusia sebelum tahun 2008. Stigma ini juga diperkuat dari hasil penelitian Wulandari (2013) yang menyatakan bahwa secara umum masyarakat mengenal dan mempersepsikan Purwakarta hanyalah sebagai kota perlintasan dan kawasan penyangga industri Bekasi dan Karawang. Dalam upaya menepis stigma selama kurang lebih dua dekade dengan sebutan sebagai "Kota Pensiun", kini pemerintahan kabupaten Purwakarta secara bertahap menata diri melalui berbagai pembangunan yang dapat mengangkat sektor ekonomi dan kesejahteraan masyarakat menuju sebagai “Kota Sejuta Impian”. Selain itu, secara sosiodemografis posisi kabupaten Purwakarta yang terletak dipersimpangan 
jalan nasional yang menghubungkan Jakarta sebagai Ibu Kota Negara dengan Bandung sebagai Ibu Kota Provinsi Jawa Barat, dan yang menghubungkan Jakarta dengan Cirebon dapat dijadikan sebagai modal dasar untuk mewujudkan kemajuan masyarakat melalui pembangunan yang berkelanjutan.

Sebelum Bupati Dedi Mulyadi menjabat pada tahun 2008, pola pembangunan yang dilakukan di kabupaten Purwakarta masih bersifat pembangunan yang kurang memihak pada masyarakat. Hal ini terbukti dari hasil capaian pembangunan fisik dan mental yang dirasakan oleh masyarakat dianggap tidak ada perubahan, yaitu tetap sepi sebagai kota perlintasan jalur distribusi logistik yang menghubungkan kawasan Jakarta-Bandung maupun Pantai Utara Jawa (Pantura). Tetapi, sejak kepemimpinan beliau, wajah kabupaten Purwakarta "disulap" menjadi kota yang cantik dan memikat bagi masyarakat Purwakarta, Jawa Barat, bahkan dunia internasional. Beberapa hasil pembangunan infrastruktur selama 10 tahun terakhir (2008-2018) yaitu revitalisasi taman-taman kota yang tematik Kesundaan, bangunan gedung pemerintahan bercirikan atap khas budaya Sunda dengan pagar berbentuk kuncup bunga Melati, layanan publik yang serba teknologi dan berbasiskan rasa kemanusiaan yang tinggi, serta pelaksanaan penyambutan HUT kabupaten Purwakarta yang dikemas dalam bentuk festival budaya.

Berkat pembangunan infrastruktur Purwakarta yang berwawasan budaya khususnya, kini terkenal di seantero Indonesia bahkan hingga ke mancanegara. Bahkan, Purwakarta menjadi target destinasi wisata baru bagi masyarakat di Jawa Barat. Sebagaimana hal ini diungkapkan oleh Ibu Ida selaku Sekretaris Diskominfo Purwakarta yang mengatakan bahwa banyak kegiatan seperti festival budaya Purwakarta Istimewa yang diselenggarakan setiap tahunnya dalam rangka menyambut HUT Kabupaten Purwakarta yang dapat mendatangkan calon wisatawan dari dalam negeri bahkan mancanegara. Adanya festival budaya ini telah mengubah wajah kabupaten Purwakarta menjadi salah satu kota yang berkomitmen untuk melestarikan nilainilai budaya lokal Sunda sejak kepemimpinan Bupati Dedi Mulyadi. Yang di mana menurut Herladianti, Damayanti, \& Prastowo, (2016 ) bahwa masyarakat Purwakarta sendiri kini sudah menyadari pentingnya adat Sunda yang sudah cukup lama ditinggalkan dalam mengisi kehidupan bermasyarakat, termasuk dalam konteks pembangunan. Bupati Purwakarta Dedi Mulyadi berupaya untuk menghidupkan kebudayaan Sunda baik dari segi keseniannya, pakaian adat, rumah- rumah adat, hingga kearifan lokal masyarakatnya (Ainun Soffani \& Nugroho, 2019) 
Keberhasilan kabupaten Purwakarta menjadi terkenal dalam pariwisatanya tidak terlepas dari peran stakeholders yang berupaya meningkatkan pembangunan yang berwawasan nilai-nilai budaya. Keberadaan stakeholders ini menjadi kunci utama tercapainya prestasi Purwakarta Istimewa sebagai sasaran utama dari beberapa prestasi yang disampaikan ke pemerintahan kabupaten Purwakarta. Adapun yang dimaksud dengan stakeholders adalah sebagai semua orang atau kelompok yang memiliki ketertarikan dalam proyek atau dapat dipengaruhi oleh luaran (output) yang dilakukan oleh organisasi. Mereka adalah individu atau organisasi yang bisa mempengaruhi dan dipengaruhi oleh kebijakan suatu organisasi lainnya (M. E. Susilo, Prayudi, \& Erawati, 2016).

Adanya keterlibatan stakeholders dalam pembangunan di kabupaten Purwakarta yaitu bisa berasal dari pihak-pihak yang terkait seperti pemerintah, masyarakat, LSM, media massa, budayawan, akademisi, agamawan, investor dan pengusaha yang bisa menerima maupun menentang terhadap proses kebijakan pembangunan yang ada di kabupaten Purwakarta (Adrian \& Maharani, 2018). Keterlibatan stakeholders khususnya pihak swasta dan masyarakat tentunya dapat meredam potensi konflik yang terjadi dalam upaya membangun Purwakarta Berkarakter dan Istimewa.
Dengan melibatkan berbagai unsur kepentingan dalam proses pembangunan yang dilandasi dengan saling berkerjasama akan menghasilkan kesadaran dan ikut bertanggungjawabnya terhadap perencanaan, pelaksanaan dan pengawasan hasil-hasil pembangunan yang sudah tercapai, terutama dalam hal membangun identitas daerah.

Pada tataran pelaksanaan keterlibatan stakeholders dalam membangun Purwakarta sedikitnya mengalami permasalahan. Dimana fokus permasalahan yang dihadapi adalah keterbatasan dan kewenangan bagi stakeholders untuk berkontribusi lebih dan berkelanjutan dalam membangun ide gagasan maupun infrastruktur di wilayah kabupaten Purwakarta. Keterbatasan dan kewenangan diakibatkan masih kuatnya figur sang Bupati sebagai pencetus dan tokoh sentral perubahan paradigma pembangunan di kabupaten Purwakarta.

Atas capaian pembangunan semasa Bupati Dedi Mulyadi yang dirasakan, masyarakat secara langsung memberikan dukungan yang kuat terhadap proses pembangunan Purwakarta yang berwawasan budaya. Prestasi pembangunan fisik ini juga didukung dengan peningkatan indeks pembangunan manusia (IPM) di Purwakartka yang ditunjukkan dengan capaian angka harapan hidup (AHH) masyarakat Purwakarta dari sepuluh tahun terakhir terus meningkat, dan pada tahun 
2018 mencapai angka 70,42 (BPS, 2018). Hal ini terlihat dari banyaknya masyarakat yang berdatangan ke taman-taman yang ada di Purwakarta, terkhusus untuk menyaksikan air mancur Situ Buleud. Peningkatan angka harapan hidup masyarakat Purwakarta ini menunjukkan bahwa pembangunan Purwakarta bukan hanya sekedar memprioritaskan pada sektor pembangunan fisik saja melainkan juga pada sektor manusianya sebagai pengendali proses pembangunan fisik secara berkelanjutan. Selain itu, artinya dengan adanya peningkatan IPM Purwakarta menandakan bahwa kabupaten Purwakarta dianggap mampu bersaing dengan kota dan kabupaten yang ada di Jawa Barat terkait proses pembangunan daerah yang selama ini dilakukan oleh pemerintahan, masyarakat, dan unsur terkait lainnya yang ada di Purwakarta.

Berdasarkan kondisi empiris tersebut, maka rumusan dalam penelitian ini adalah bagaimana peranan stakeholders Purwakarta dalam membangun identitas daerah yang berwawasan nilai budaya lokal Sunda dalam tata kelola pemerintahan di wilayah kabupaten Purwakarta. Tujuan penelitian ini adalah untuk mengetahui dan menjelaskan permasalahan dan peranan stakeholders (para pemangku kepentingan) dalam membangun suatu identitas Purwakarta sebagai daerah yang berwawasan nilai budaya lokal yang mengitegrasikan antara perkembangan ilmu pengetahuan dan teknologi dalam mewujudkan kesejahteraan dan pemerataan bagi masyarakat.

\section{METODE PENELITIAN}

Penelitian ini menggunakan paradigma postpositivistik dengan metode penelitian deskriptif kualitatif. Menurut Bogdan dan Taylor dalam Gifari metode kualitatif dapat diartikan sebagai prosedur penelitian yang menghasilkan data deskriptif berupa kata-kata yang tertulis atau lisan dari orang-orang atau perilaku yang dapat diamati dan diarahkan pada latar dan individu secara utuh (Gifari \& Purnama, 2017). Lebih lanjut, Moleong menjelaskan bahwa dalam metode deskriptif, data yang dikumpulkan dapat berupa kata, kalimat, gambar/model dan bukan angka-angka yang dimaksud dihasil dari pengolahan data statistik (Moleong, 2000).

Oleh karena itu, peneliti hanya memaparkan dan menggambarkan situasi sesuai keadaan yang sebenarnya agar menghasilkan data seobjektif mungkin.

Pada penelitian ini, data dikumpulkan melalui kegiatan observasi, wawancara, focus group discussion (FGD), dan studi pustaka mengenai peranan stakeholders di kabupaten Purwakarta dalam membangun daerah Purwakarta yang beridentitas sebagai salah satu kota budaya yang ada di Jawa Barat. Adapun teknik pemilihan key informant yang digunakan 
yaitu bersifat purposif. Untuk pengambilan data dengan teknik wawancara dilakukan sesuai pedoman wawancara yang diperuntukkan bagi pimpinan atau staf pegawai kedinasan yang terkait dengan pembangunan yang ada di lingkungan kabupaten Purwakarta sebagai key informant yang dipilih sesuai kriteria penelitian. Untuk teknik observasi, peneliti dilengkapi dengan pedoman observasi mengenai capaian pembangunan infrastruktur di kabupaten Purwakarta yang dapat dikategorikan sebagai objek bangunan yang berwawasan nilai-nilai budaya Sunda. Sedangkan FGD dilakukan sebagai bagian dari teknik validitas data dengan narasumbernya adalah pimpinan dari lembaga-lembaga yang terkait dalam persoalan pembangunan wilayah Purwakarta berkarakter dan Istimewa dan penggunaan studi literatur diutamakan konsep dan peraturan atau kebijakan yang terdokumentasikan di lembaga pemerintahan yang menangani persoalan pembangunan Purwakarta yang beridentitas.

Teknik analisis data dilakukan sejak awal pengumpulan data berupa hasil wawancara mendalam, FGD, dan pengamatan yang disajikan dalam bentuk resume penelitian yang dianalisis sejak pertama kali survey datang ke lapangan yang dilakukan secara kontinu yang terdiri daripengumpulan data, analisis data, reduksi data, penyajian data, dan penarikan kesimpulan.

\section{HASIL DAN PEMBAHASAN}

Sebutan "Kota Pensiunan" bagi kabupaten Purwakarta telah memudar seiring dengan perkembangan pembangunan selama 10 tahun terakhir (2008-2018) telah berubah menjadi salah satu kabupaten favorit destinasi wisata Jawa Barat.

Pada dasarnya pengembangan pembangunan pada hakikatnya melibatkan paling sedikit tiga stakeholders dimana ketiganya saling berkaitan satu dengan yang lain, tiga stakeholders yang dimaksud dalam hal ini adalah pemerintah daerah, pihak swasta, dan masyarakat. Merujuk pada keterlibatan tersebut, maka adanya kerjasama ketiga stakeholders di kabupaten Purwakarta telah memberikan perubahan yang sangat signifikan menjadikan Purwakarta sebagai kabupaten yang berkarakter tanpa meninggalkan jejak sejarah dan kebudayaan masyarakat Sunda.

Beberapa hasil karya pembangunan infrastruktur di kabupaten Purwakarta yang menjadi ciri unik yang beridentitas sebagai kota tujuan wisata yaitu air mancur Situ Buleud Sri Baduga yang merupakan air mancur terbesar di Asia Tenggara yang dikemas sangat artistik. Selanjutnya, berbagai museum yang berbasis budaya seperti Museum Galeri Wayang dan Museum Diorama yang menyajikan sejarah kebudayaan Sunda beserta asal mula lahirnya 
kabupaten Purwakarta yang dipadukan dengan teknologi informasi, taman-taman tematik, dan program-program layanan dasar kemasyarakatan yang diluncurkan oleh pemerintah kabupaten Purwakarta. Dalam upaya mewujudkan pembangunan mental masyarakat dilakukan secara bekerjasama antara pihak pemerintah, tokoh agama, pendidikan, budaya dan masyarakat pada umumnya dengan mengutamakan filosofi nilai budaya Sunda pada program pembangunannya. Dengan demikian, pembangunan infrastruktur di kabupaten Purwakarta dilakukan untuk memberikan identitas atau jati diri yang positif agar masyarakat bangga bahwa Purwakarta telah maju dalam pembangunan tata wilayah perkotaannya. Sedangkan pembangunan manusia (masyarakat) Purwakarta ditujukan untuk dapat meningkatnya angka kebahagian dana harapan hidup masyarakat menjadi lebih baik lagi secara kualitas. Dengan begitu, pembangunan sebagai bagian dari suatu identitas daerah akan memberikan kemudahan dalam menunjukkan keunggulan suatu daerah melalui pemberian informasi yang cepat dikenali oleh berbagai macam publik nantinya, terutama dalam hal capaian pembangunan yang sudah dilakukan (Barata, Dektisa, \& Arini, 2015).

Saat ini Purwakarta telah menjadi ikon spirit pembangunan dan percontohan bagi daerah di provinsi Jawa Barat dengan menampilkan dan mengkreasikan pilar pondasi budaya Sunda dalam menatap dan menata masa depan kemajuan daerah melalui proses pembangunan mental dan fisik secara terencana. Maka dari itu, setiap upaya pengembangan pembangunan di kabupaten Purwakarta harus memiliki tujuan dalam rangka meningkatkan kapasitas dan kapabilitas budaya lokal agar dapat menjadi pelengkap dan sebagai sumber inspirasi peningkatan tata kelola pemerintahan dan perkotaan yang berwibawa, bermanfaat, dan terbuka bagi masyarakat secara umum.

Kebijakan pemerintah dalam pembangunan suatu wilayah merupakan kunci utama dalam penyelenggaraan tata kelola pemerintahan yang baik dan yang memihak pada kepentingan masyarakat. Kebijakan adalah suatu taktik dan strategi yang diarahkan untuk mencapai tujuan tertentu. Sedangkan kebijakan pemerintah menurut James Andarson merupakan kebijakan yang disusun oleh lembaga-lembaga pemerintah dan pejabat-pejabat pemerintah (dalam Djaenuri, 2015). Sebagai bagian dari kebijakan pemerintah yang sangat strategis bagi pemerintah daerah berupa kewenangan di era otonomi daerah, seharusnya pemerintah kabupaten/kota/provinsi memiliki peluang yang besar dalam mengkreasikan kebijakan yang bersumber pada ide-ide gagasan sumber pendapatan pembangunanmaupunimplementasi pembangunan yang berpihak pada masyarakat, 
investor, maupun publik lainnya. Hal ini sebagaimana dinyatakan oleh Sedarmayanti, (2018) yang menyebutkan otonomi daerah merupakan wewenang untuk mengatur dan mengurus rumah tangga daerah yang melekat dalam menjalankan pemerintahannya, termasuk dalam hal pengelolaan proses pembangunan di daerah.

Purwakarta sebagai daerah yang sedang mengalami transisi perubahan dari kawasan pertanian menuju ke industri yang dikarenakan secara sosiogeografis berdekatan dengan kawasan pengembangan industri Jakarta, Bekasi, dan Karawang yang dapat melahirkan keragaman produktivitas, perilaku masyarakat, dan budaya. Lahirnya keragaman tersebut dapat mempengaruhi kebijakan pemerintah, sehingga pemerintah Kabupaten Purwakarta merasa berkepentingan dalam melaksanakan otonomi daerahnya melalui proses pembangunan fisik maupun mental yang memiliki identitas daerah. Berbicara mengenai identitas, tidak akan lepas dari budaya. Hal tersebut ditegaskan oleh definisi dari Littlejohn \& Foss (dalam Susilo, 2013) yang menjelaskan bahwa "identity is defined as the cultural..." (identitas adalah budaya...). Dengan berbasiskan pada nilainilai kearifan lokal budaya Sunda, Purwakarta berupaya untuk mendapatkan identitas kedaerahan dalam membangun wilayahnya sehingga dapat diketahui oleh masyarakat lokal, nasional, dan bahkan mancanegara. Sedangkan kearifan lokal itu sendiri adalah suatu gagasan setempat (kedaerahan) yang bersifat bijaksana, penuh kearifan, bernilai baik, yang tertanam dan diikuti oleh anggota masyarakatnya (Hariyanto, 2017)

Mewujudkan kewenangan otonomi daerah, pendekatan pembangunan daerah Purwakarta dilakukan dengan berbasiskan wawasan budaya Sunda dicetuskan oleh Bupati Dedi Mulyadi sejak tahun 2008. Otonomi daerah sendiri menurut Mulyadi (2012) yang berarti keleluasaan (discretionary), kekebalan (imunity), dan kemampuan (capacity) daerah dalam mengambil keputusan dan menggunakan kewenangan untuk mengelola sumber daya lokal. Pendekatan pembangunan yang berwawasan budaya di Purwakarta merupakan suatu upaya menempatkan budaya Sunda yang merupakan warisan adiluhung wilayah Jawa Barat sebagai marwah dan roh spirit pembangunan untuk mewujudkan kemajuan dan kesejahteraan bagi warga. Dalam upaya mencapai tujuan pembangunan, bentuk identitas hasil pembangunan Purwakarta saat ini merupakan hasil perumusan dari pimpinan daerah yaitu Bupati atas nama pemerintah kabupaten dengan Satuan Kerja Perangkat Daerah (SKPD) selaku pelaksana kebijakan. Selanjutnya, untuk mendapatkan identitas pembangunan Purwakarta yang berlandaskan 
pada nilai-nilai budaya Kesundaan yang berkelanjutan dan bukan hanya sebagai program mercusuar saja, maka diperlukan suatu dasar yang kuat secara aspek hukum dan sosiologis untuk dapat merealisasikan konsep-konsep tersebut yang mudah dipahami dan dilakukan oleh berbagai kelompok kepentingan, terutama pemerintah, pihak swasta, dan masyarakat.

Salah satu kelompok kepentingan dalam proses pembangunan, yaitu pemerintah selaku pihak yang memiliki kewenangan dan kekuasaan dalam merencanakan dan melaksanakan pembangunan di daerahnya dengan cara mengeluarkan aspek regulasi sebagai pedoman atau rujukan dalam bentuk kebijakan yang dapat memperlancar proses pembangunan yang dituangkan dalam Peraturan Daerah, Peraturan Bupati, Keputusan Bupati, dan Instruksi Bupati. Hal ini pula yang dilakukan oleh pemerintah kabupaten Purwakarta dalam melaksanakan proses visi pembangunan jangka menengah yang berwawasan nilai budaya lokal yaitu Purwakarta Berkarakter dalam bentuk Peraturan Daerah Kabupaten Purwakarta. Adapun penjelasan dari visi "Purwakarta Berkarakter" berdasarkan Perda No. 13 Tahun 2015 tentang RPJMD Kabupaten Purwakarta 2013-2018 yaitu pola pembangunan terintegrasi yang didasarkan pada persenyawaan nilai dasar tanah, air, udara, dan matahari sebagai basis penciptaan manusia yang tercermin dari tata kota dan bangunan, tata kelola pemerintahan, tata kehidupan masyarakat yang berorientasi pada kemanunggalan, keparipurnaan dan kemuliaan sebagai bentuk pertanggungjawaban keterwakilan manusia di muka bumi yang dipilih oleh Allah SWT sebagai makhluk yang istimewa.

Dalam rangka mencapai visi pemerintah kabupaten Purwakarta dimaksud diperjelas lagi dalammisiprogrampembangunanyangberfungsi sebagai pemersatu gerak, langkah, dan tindakan nyata bagi segenap komponen penyelenggara pemerintahan tanpa mengabaikan mandat yang diberikannya. Adapun makna dari misi dalam upaya pencapaian visi Purwakarta Berkarakter adalah yang terkait dengan peran stakeholders adalah mengembangkan pembangunan berbasis kearifan lokal yang bernilai religius, berorientasi pada keunggulan pendidikan, kesehatan, kesejahteraan sosial dan pemerataan ekonomi yang berkeadilan bagi seluruh masyarakat. Pengertian dari misi ini adalah pengembangan pembangunan yang berbasis kearifan lokal yang bernilai religius yang dapat ditempuh dengan meningkatkan aksesibilitas dan kualitas pendidikan, meningkatkan peran aktif seluruh stakeholders dalam pembangunan mental masyarakat, meningkatkan, dan tetap mempertahankan nilai-nilai budaya dan kearifan lokal, meningkatkan derajat kesehatan masyarakat serta meningkatkan kesejahteraan 
sosial masyarakat melalui pembangunan di sektor ekonomi yang berkelanjutan yang sesuai dengan talenta atau kepribadian masyarakat Purwakarta. Untuk memahami suatu pembangunan bersifat berkelanjutan, maka merujuk pada hasil penelitian dari Luqman, Sumardjo, Sarwoprasodjo, \& Tambunan, (2017) yang menyatakan bahwa dengan memperhitungkan karakteristik spesifik pembangunan berkelanjutan memiliki implikasi besar bagi proses komunikasi yang akan diterapkan untuk memfasilitasi inisiatif pembangunan wilayah yang beridentitas budaya lokal.

Selanjutnya, sebagai bagian dari stakeholders pembangunan di Purwakarta, lembaga pemerintahan kedinasan di kabupaten Purwakarta berperan sebagai pelaksana program pembangunannya yang menyelaraskan dengan visi yang telah ditetapkanoleh Bupati Purwakarta yaitu berlandaskan pada nilai-nilai kearifan lokal Sunda yang merupakan terjemahan dari visi dan misi kebijakan pimpinan daerah. Dalam implementasinya, program pembangunan yang dilaksanakan oleh dinas pemerintahan terkait memiliki kekuatan hukum tetap di masyarakat dan dapat dipertanggungjawabkan. Dengan demikian, peran kebijakan pemerintah daerah dalam membangun identitas Purwakarta dibuat dalam bentuk peraturan, kebijakan, dan kebijaksanaan yang harus didukung oleh sumber daya manusia dan sumber daya keuangan yang baik sesuai dengan prioritas pembangunan yang berkarakter untuk melayani masyarakat. Yang dimaksud dengan sumber daya manusia itu tiada lain dalam konteks pembangunan di Purwakarta adalah para pegawai negeri di lingkungan pemerintahan kabupaten Purwakarta yang diharapkan dapat menjadi komunikatorkomunikator andal dalam mensosialisasikan visi dan misi pembangunan Purwakarta Berkarakter dan Istimewa sebagai bagian dari komunikasi pemerintahan yang terbentuk. Adapun bentuk komunikasi pemerintahan kepada masyarakat menurut Mulyana (2001) melalui keterbukaan, dialog, dan kepekaan mendengarkan suara berbagai pihak, sebagai wahana bagi penyelesaian berbagai masalah di daerah, termasuk masalah pembangunan.

Pada akhirnya, peran kebijakan pemerintah kabupaten Purwakarta pada pelaksanaan pembangunan mempunyai kedudukan yang strategis dalam usaha mewujudkan pemerintahan yang bersih, dari korupsi, kolusi, dan nepotisme serta akuntabel. Seiring dengan hal itu, maka pemimpin di setiap SKPD pemerintahan kabupaten Purwakarta diharapkan dapat memperhatikan, memahami dan mampu menerapkan prinsip-prinsip penyelenggaraan kebijakan pembangunan yang berlandaskan pada nilai-nilai lokalitas kesundaan, dalam kerangka mencapai tujuan pemerintahan 
kabupaten yang dicita-citakan yaitu Purwakarta Berkarakter dan Purwakarta Istimewa.

Adapun program pemerintahan kabupaten Purwakarta dalam mewujudkan pembangunan yang berwawasan nilai budaya terdiri atas program pembangunan pada sektor fisik dan mental. Untuk sektor pembangunan fisik, program pembangunan yang dilaksanakan meliputi pembangunan jalan dan jembatan, revitalisasi pasar tradisional, pembangunan ruang terbuka hijau berupa taman-taman tematik, pembangunan identitas gedung pemerintahan berupa atapjulang ngapak dan bunga melati pada pilar/pagar gedung, dan pembangunan patungpatung tokoh pewayangan, tokoh nasional, dan hiasan peralatan Sunda di persimpangan jalan kota Purwakarta, dan revitalisasi layanan masyarakat yang berbasis teknologi informasi.

Sebagai bagian dari pembangunan fisik, pembangunan infrastruktur menjadi salah satu agenda prioritas dalam Rencana Pembangunan Jangka Menengah Nasional 2015-2019 dalam mewujudkan program Nawacita pemerintahan pusat. Hal ini karena dianggap bahwa pembangunan infrastruktur memiliki peran penting dalam memacu pertumbuhan ekonomi, kesejahteraan rakyat dan daya saing nasional.

Pembangunan sektor mental di kabupaten Purwakarta lebih dititikberatkan pada program-program peningkatan kualitas kinerja PNS, kualitas pendidikan masyarakat yang berkarakter, kualitas kesehatan masyarakat murah dan terjangkau, kualitas layanan administrasi kependudukan, dan jaminan kesejahteraan bagi masyarakat miskin. Selain itu, pembangunan lainnya yaitu pembangunan mental yang bersifat strategis mulai dari kebijakan tata kota, tata bangunan, sistem pengelolaan pemerintahan desa, sampai pada sistem pelayanan pemerintah.

Semua program pembangunan di atas merupakan ide dan gagasan yang dilontarkan oleh Bupati Dedi Mulyadi. Dengan mempunyai prinsip yang kuat, kokoh dan kenyakinan logika kebenaran yang dimiliki oleh Bapak Bupati agar warga Purwakarta memiliki kesadaran diri tentang identitas bangsanya, identitas lingkungannya, dan identitas bangsanya sehingga ada optimalisasi nilai-nilai mulai dari persoalan peningkatan kualitas bahasa lokal sampai dengan persoalan desain dan branding khas Purwakarta. Kebijakan-kebijakan yang diwujudkan tersebut secara umum relatif diterima oleh masyarakat, dengan menggunakan idiom-idiom Sunda yang diangkat ke level operasional pembangunan di Kabupaten Purwakarta menjadi ciri khas tersendiri bagi pola pembangunan yang telah berjalan selama ini yang menjadi identitas daerah Purwakarta.

Pada prakteknya, proses pembangunanyang saat ini dilakukan oleh pemerintahan kabupaten Purwakarta merupakan hasil kolaborasi antar 
sektor kepentingan yang dapat menjadi kunci sukses keberhasilan suatu pembangunan yang berkelanjutan dan beradab. Bentuk kolaborasi minimal yang diterapkan adalah Triple Helix yang meliputi unsur pemerintah, sektor swasta, dan masyarakat yang memerankan peran aktif dalam bentuk kemitraan. Lebih jauhnya lagi seharusnya pembangunan itu merupakan hasil kolaborasi yang bersifat Penta Helix (Pemerintah, Swasta, Media Massa, Akademisi, dan Masyarakat). Dengan kata lain, Penta Helix merupakan suatu strategi yang perlu dikembangkan melalui dukungan dari berbagai lintas lembaga (Pratiwi, Dida, \& Sjafirah, 2018). Sebagai kabupaten yang menggeliat dibidang pembangunan, komponen minimal kolaborasi pembangunan di kabupaten Purwakarta sudah terpenuhi dengan baik.

Unsur pemerintah sebagai bagian dari startegi Triple Helix dalam proses pembangunan di Purwakarta memiliki peran sangat strategis dan sentral dalam menentukan arah kebijakan pembangunan wilayah yang akan dicapai. Sebab pemerintah sebagai salah satu unsur yang penting dari suatu negara mempunyai posisi yang dicerminkan dalam kaitannya dengan penyelenggaraan pemerintahan secara internal maupun eksternal.

Lembaga pemerintahan, dalam praktik proses pembangunan di kabupaten Purwakarta dihadapkan pada terobosan yang inovatif dan kreatif sesuai dengan semangat pemimpin daerah, yaitu Bupati Purwakarta yang mencanangkan implementasi pembangunan infrastruktur dan layanan kemasyarakatan di wilayah Purwakarta harus diikuti dengan nilai rasa bukan sekedar memenuhi target mata anggaran yang direncanakan dalam APBD yang bersifat kuantitatif. Namun, itu semua harus dapat dilaksanakan sesuai dengan fungsi pemerintahan kabupaten dalam mewujudkan program-program pembangunan yang pro rakyat.

Pemerintahan Purwakarta dalam implementasi kebijakan pembangunan yang berlandaskan pada nilai budaya lokal berfungsi sebagai poros utama yang bukan sekedar berperan untuk memfasilitasi maupun mengkoordinasikan tujuan pembangunan. Tetapi, fungsi kebijakan tersebut erat kaitannya dengan organisasi pemerintahan, pemimpin pemerintahan, masyarakat yang diperintah, asas pemerintahan, lingkungan pemerintahan, sistem pemerintahan, maupun etika pemerintahan, yang kesemuanya itu menuntut penanganan yang seksama agar tujuan pemerintahan kabupaten Purwakarta yang telah dicanangkan dalam Rencana Pembangunan Jangka Menengah Daerah (RPJMD) dapat tercapai secara efisien dan efektif. Hal ini sesuai dengan realitas dilapangan bahwa kolaborasi pemerintahan dengan pihak lain mengenai suatu keputusan 
pelaksanaan program pembangunan yang menghasilkan suatu kebijakan akan memiliki tujuan untuk tercapainya kesejahteraan dan pemerataan baik pada skala lingkungan desa/ kelurahan maupun kecamatan yang ada di tiga wilayah pengembangan pembangunan Purwakarta.

Melalui fungsi kebijakan pimpinan daerah dalam hal pembangunan yang berwawasan budaya dan nilai-nilai lokal dituangkan pada tupoksi setiap SKPD yang dapat memberikan kemudahan untuk mengimplementasikan program-programpembangunanyangprorakyat, seperti program pembangunan yang langsung menyentuh kebutuhan dasar masyarakat seperti pembangunan pada sektor peningkatan kualitas pelayanan dasar pendidikan, kesehatan, infrastruktur, serta pelayanan prima bagi masyarakat. Sebagaimana hal ini diungkapkan oleh pegawai Dinas Pendidikan kabupaten Purwakarta yang mengutarakan bahwa:

"...penerapan pembangunan yang berwawasan budaya di bidang pendidikan dilakukan melalui program Pendidikan Istimewa, peserta didik harus bawa makanan sendiri dari rumah, prelek bagi siswa, nama tokoh Sunda di setiap sekolah..."

Dari hasil wawancara diatas dapat dijelaskan bahwa program pembangunan di bidang pendidikan, pemerintah kabupaten Purwakarta melahirkan pola pendidikan yang menitikberatkanpada kebersamaan, kepedulian, dan kematangan emosi bagi peserta didik dan guru. Nilai-nilai pedidikan ini merupakan karakter dari masyarakat Sunda yang mengharapkan generasi selanjutnya menjadi generasi yang Cageur, Bageur, Bener, Pinter, dan Singer.

Hal yang serupa disampaikan oleh Pegawai Dinas Bina Marga dan Tata Ruang kabupaten Purwakarta yang menyatakan bahwa:

“...pembangunan di Purwakarta diutamakan pada pembangunan infrastruktur keterhubungan jalan antardesa hingga lucir, revitalisasi tamantaman tematik kota yang bernuansakan nilai budaya Sunda, serta revitalisasi fungsi gedung-gedung sejarah yang ada seperti bangunan gedung kembar dekat stasiun Purwakarta...."

Berdasarkan pernyataan dari salah satu pegawai Dinas Bina Marga dan Tata Ruang diatas menunjukkan bahwa sasaran kesejahteraan bagi masyarakat Purwakarta selama ini adalah kondisi jalan yang kurang bagus yang dapat menghambat lajunya perekonomian antar desa, antar kecamatan, maupun antar kabupaten yang selama ini menjadi salah satu faktor terbelakangnya peningkatan kesejahteraan masyarakat.

Kedua pernyataan diatas merupakan contoh dari bagaimana bangga nya masyarakat terhadap kebijakan pembangunan yang dilakukan oleh pemerintah kabupaten Purwakarta. Artinya disini keberadaan lembaga pemerintahan dan pimpinan daerah berperan dalam menyediakan infrastruktur 
dan kerangka regulasi yang dapat mendorong pihak swasta dan masyarakat ikut berpartisipasi aktif dalam proses pembangunan (Evadianti, 2017), terkhusus di wilayah Purwakarta yang pembangunan yang berbasiskan pada wawasan budaya Sunda. Selanjutnya, kebijakan pimpinan daerah mempunyai peranan yang sentral atas keberhasilan penyelenggaraan pemerintahan yang dapat menjadi figur yang menentukan terhadap efektifitas pencapaian tujuan organisasi pemerintahan. Dengan kata lain, pencapaian target pembangunan suatu daerah ditentukan oleh kemampuan, kompetensi, dan kapabilitas pemimpin pemerintahan dalam melaksanakan tugas dan fungsinya. Begitu halnya dengan fungsi kebijakan yang dikeluarkan oleh Bupati Purwakarta terkait dengan pembangunan identitas wilayah yang berlandaskan nilai lokalitas diterapkan ke berbagai unsur kehidupan tata kelola pemerintahan dan bermasyarakat.

Fungsi kebijakan dalam konteks pembangunan di Purwakarta tiada lain untuk mendapatkan identitas dan juga dalam rangka untuk meningkatkan gairah pertumbuhan industri dan partisipasi masyarakat dalam pembangunan. Yang dimana sistem perencanaan pembangunan yang diterapkan di Purwakarta telah membuka secara top-down melalui regulasi dan bottom-up dengan partisipasi masyarakat. Sehingga fungsi kebijakan yang berbasis budaya lokal ini semua elemen masyarakat merasa

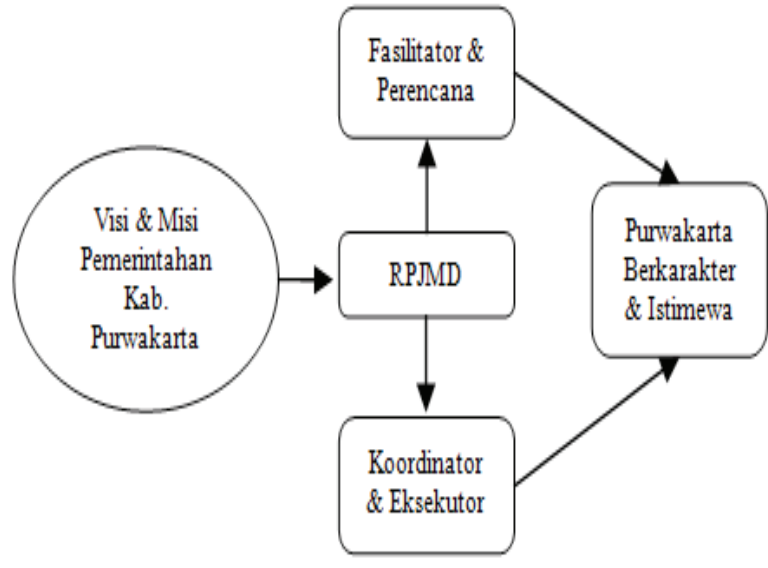

Sumber: Hasil Penelitian, 2018

Gambar 1 Peran Pemerintah dalam Pembangunan Purwakarta Berkarakter dan Istimewa

memiliki bahwa pembangunan di Purwakarta itu adalah tanggungjawab bersama dengan posisi pemerintah berperan sebagai fasilitator, koordinator, dan eksekutor yang proaktif, dengan cara terjun langsung untuk berdialog dengan pihak swasta dan masyarakat untuk merumuskan dan melaksanakan pembangunan yang bermanfaat bagi semua pihak.

Berdasarkan tampilan gambar 1 dapat dijelaskan bahwa peran pemerintah kabupaten beserta perangkat satuan kedinasan sebagai bagian dari stakeholders dalam pembangunan yang berbasiskan nilai-nilai budaya Sunda harus semaksimal mungkin menjadi perencana, fasilitator, koordinator, dan eksekutor yang sesuai dengan prinsip-prinsip tata kelola pemerintahan yang baik yaitu terbuka, akuntabel, dan bebas KKN.

Adapun wujud program pembangunan Purwakarta yang berkarakter dan istimewa 
dapat diperinci ke dalam sektor pembangunan dasar kebutuhan masyarakat diantaranya dalam program pengelolaan dan pelayanan kesehatan berupa Jaminan Kesehatan Purwakarta (Jampis) dan layanan kesehatan berbasis teknologi informasi yang dinamai "SEMAR", kependekan dari Safety Emergency Medical Rescue seperti Dokter on Call, Bidan on Call,dan Ambulance on call. Pada sektor pendidikan para guru dihimbau untuk memberikan pendidikan dan pengetahuan dengan berdasarkan 7 hari atikan (pendidikan) Purwakarta Istimewa dengan setiap harinya peserta didik diwajibkan untuk dapat mempelajari perpaduan mata pelajaran sekolah yang berbasiskan pada ilmu pengetahuan, agama, dan budaya. Untuk tata kelola layanan dasar bagi masyarakat, para aparatur sipil negara (ASN) dilibatkan secara sengaja dalam acara gempungan dengan masyarakat untuk menyawalakan program-program pembangunan yang ada di wilayah Purwakarta yang sekaligus dengan menyajikan pelayanan teknis yang dibutuhkan oleh masyarakat seperti pembuatan e-ktp, akte kelahiran, SIM, SIUP, dan sebagainya. Selain itu, dalam hal hidangan makanan bagi para tamu yang datang ke lembaga pemerintahan harus jenis makanan dan minuman Sunda yang berasal dari umbi-umbian dan olahan seperti ubi rebus, singkong rebus, kacang rebus, bandrek, bajigur, katimus, opak, dan sebagainya.
Untuk stakeholders yang kedua dari Triple Helix pada proses pembangunan Purwakarta yaitu sektor swasta. Untuk membangun wilayah Purwakarta yang bercirikan dan berwawasan budaya saat ini sudah harus berpikir secara kolaboratif dengan berbagai pihak. Kabupaten Purwakarta tidak bisa dibangun oleh pihak pemerintah saja, namun perlu juga dukungan dan bantuan dari sektor swasta. Sehingga dalam pembangunan ke depannya pemerintahan kabupaten Purwakarta mengharapkan adanya keterlibatan pihak swasta dalam mengelola proses pembangunan.

Keterlibatan pihak swasta idealnya dalam proses pembangunan yaitu lahan dan asetaset yang dimiliki oleh pemerintah kabupaten Purwakarta dapat dioptimalkan dikelola untuk kesejahteraan masyarakat. Sehingga peran pihak swasta dalam konteks pembangunan kabupaten Purwakarta berkarakter dan istimewa antara lain dalam bentuk kolaborasi program

\section{Corporate Social Responsibility}

(CSR) perusahaan dan BUMN yang ada di Purwakarta dengan program-program pemerintah untuk layanan dasar bagi masyarakat. CSR adalah sebuah tanggung jawab sosial perusahaan untuk memberikan kontibusi bagi pengembangan kesejahteraan dan ekonomi dari komunitas setempat ataupun masyarakat luas.Kegiatan CSR perusahaaan yang diintergrasikan dengan program pembangunan di kabupaten 
Purwakarta, pemerintah membuatkan dengan berbasis teknologi informasi yang disebut dengan Sistem Jaringan Peduli Rakyat (Sijiper).

Sistem aplikasi ini merupakan aplikasi berbasis website yang bertujuan untuk menjembatani keinginan warga masyarakat Purwakarta dalam mendapatkan dana bantuan atau semacamnya dari perusahaan yang ada di Purwakarta untuk pembangunan infrastruktur maupun non infrastruktur masyarakat melalui Pemerintah Daerah Kabupaten Purwakarta.

Beberapa program CSR/PKBL yang pernah dilakukan di wilayah Purwakarta antara lain dari unsur BUMN, yaitu program CSR/PKBL Perusahaan Umum Jasa Tirta II yang berkerjasama dengan pihak pemerintah, melakukan pembangunan bantuan sarana air bersih dalam rangka HUT RI BUMN Hadir Untuk Negeri di desa Babakan Cikao kecamatan Babakan Cikao kabupaten Purwakarta dan melakukan konservasi kawasan pada daerah resapan air di desa Cikaobandung kecamatan Jatiluhur kabupaten Purwakarta (Humas CNN, 2017).

Berdasarkan data webpage Humas CNNS diatas menunjukkan bahwa sektor swasta tepatnya salah satu BUMN yang ada di Purwakarta menjalin kerjasama dengan pihak pemerintah dalam rangka membangun wilayah Purwakarta agar lebih sejahtera lagi masyarakatnya dalam menghadapi kehidupan dasar manusia yang harus dipenuhi. Kontribusi terhadap pembangunan identitas daerah Purwakarta, PT. PJT II ini sudah menjadi bagian trademark dari sebuah perusahaan yang mengelola bendungan terbesar di Jawa Barat, yaitu bendungan Jatiluhur. Maka, dapat dikatakan peran BUMN di Purwakarta dalam usaha mengembangkan pembangunan yang berwawasan budaya di Purwakarta berperan sebagai mitra pembangunan.

PT. Hino Motors Manufacturing Indonesia sebagai perusahaan multinasional yang terletak di daerah industri Kawasan Industri Kota Bukit Indah, Purwakarta, Jawa Barat melakukan kegiatan CSR-nya dalam bentuk pelatihan di bidang pertanian bagi para petani budidaya Jamur di desa Pusakamulya. Program CSR ini mendapat sambutan yang baik dari pihak pemerintah kabupaten Purwakarta. Hal ini sebagaimana yang disampaikan oleh Agus Rachlan Suherlan selaku Kepala Dinas Pangan dan Pertanian Kabupaten Purwakarta yang memberikan apresiasi kepada PT. Hino yang telah konsisten memberikan bantuan pembiayaan dan pembinaan bagi para petani di wilayah Purwakarta pada umumnya (Kompasiana, 2017).

Kegiatan CSR dari PT. Hino Motors Manufacturing Indonesia sebagai perusahaan swasta telah berkontribusi dalam pembangunan Purwakarta yang berwawasan budaya dengan 
mempertahankan kawasan pertanian agar tetap menjadi kawasan penyokong kehidupan sosial budaya pertanian yang tetap mempertahankan nilai-nilai budaya Sunda dalam kegiatan pertaniannya. Sehingga wilayah selatan Purwakarta masih tetap diupayakan sebagai lokasi wisata alam yang tetap menjunjung pada nilai-nilai budaya Sunda dalam pengembangan pembangunannya, yaitu menganjurkan pada para petani untuk tetap menggunakan peralatan pertanian yang tradisional dalam mengolah lahan persawahan maupun perkebunan sayuran yang didampingi dengan pelatihan-pelatihan singkat dan praktis dari ahlinya. Dengan demikian, konsep penyaluran dana CSR merupakan konsep yang dilakukan oleh perusahaan sebagai rasa tanggung jawab perusahaan terhadap warga sekitar dalam upaya meningkatkan kelayakan dan kesejahteraanterutama dalam bidang ekonomi, kesehatan, sosial, lingkungan, dan pendidikan.

Peranan perusahaan lainnya, dalam upaya pengembangan pembangunan identitas Purwakarta sebagai kota wisata budaya yaitu menjadikan Purwakarta sebagai tempat grand launching produk smartphone asal perusahaan China, PT. Vivo Mobile Indonesia yaitu Vivo seri V15 dan V15+ yang bertempat di Taman Sri Baduga pada tanggal 5 Maret 2019. Acara grand launching produk smartphone ini menampilkan kawasan Taman Air Mancur Sri Baduga yang merupakan Taman Air Mancur terbesar di Asia Tenggara yang disiarkan secara langsung oleh 5 (lima) stasiun televisi swasta nasional Indonesia (Trans TV, Trans 7, RCTI, SCTV, dan ANTV) dan 9 (sembilan) Platform Digita l(Kumparan. com, Liputan6.com, Detikcom, Tribunnews. com, Kompas.com, Kapanlagi.com, Kaskus. co.id, TabloidPulsa.co.id, dan IDNTimes.com) dengan penataan artistik panggung terapung (floating stage) yang bekerjasama dengan pihak Transmedia. Kegiatan ini menjadi suatu kebanggaan bagi warga masyarakat Purwakarta karena diliput secara nasional. Sebagaimana hal ini diungkapkan oleh Kepala Bidang Pariwisata \& Kebudayaan Dinas Pariwisata Kebudayaan Kabupaten Purwakarta Heri Anwar dalam laman (Detik.com, 2019), yang menyatakan bahwa:

"Ini merupakan kebanggaan bagi kami Pemkab Purwakarta. Hari ini kami sudah meng-up di media sosial dan semua masyarakat bertanya-tanya karena baru pertama kali diadakan. Ini bisa memberikan citra positif khususnya pariwisata"

Pernyataan diatas menunjukkan bahwa pemilihan lokasi di Purwakarta dapat dimaknai sejalan dengan program pembangunan identitas Purwakarta sebagai kota destinasi wisata, sehingga kegiatan yang diinisiasi oleh pihak swasta ini dapat mendorong dan memajukan sektor pariwisata di Purwakarta yang semakin meningkat lagi selepas terpublikasikan di media massa maupun media sosial. Bagi 


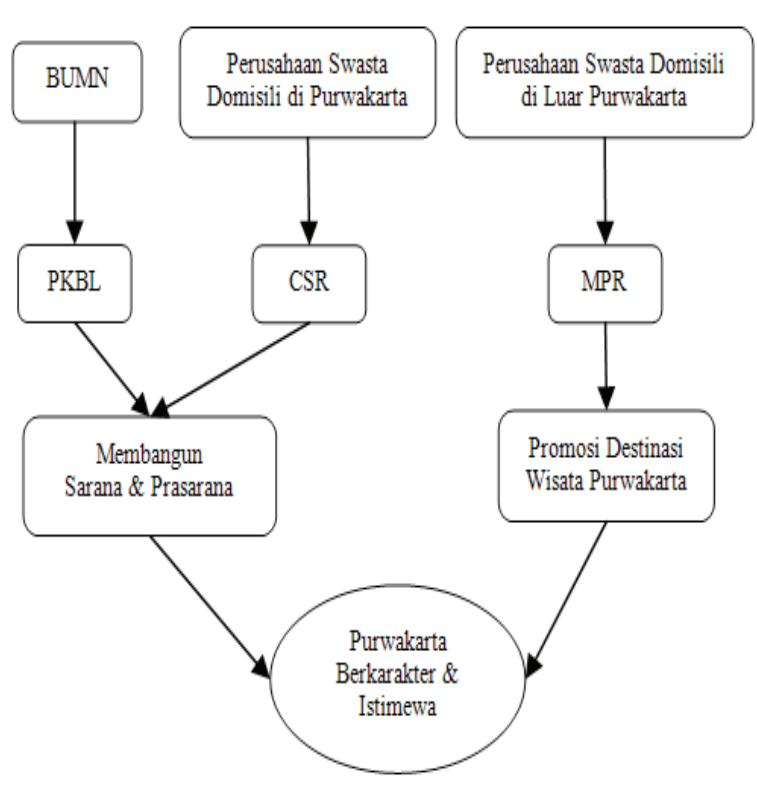

Sumber: Hasil Penelitian, 2018

Gambar 2 Peran Swasta dalam Pembangunan Purwakarta Berkarakter dan Istimewa

PT. Vivo Mobile Indonesia sendiri dengan memanfaatkan kawasan Purwakarta setidaknya telah mengangkat perusahaan itu sendiri sebagai perusahaan yang peduli terhadap pelestarian budaya yang terdapat di suatu daerah.

Dalam gambar 2 menunjukkan bahwa peranan sektor swasta dalam mendukung pembangunan Purwakarta berkarakter dan istimewa, yaitu dalam bentuk penyaluran dana yang bekerjasama dengan dinas pemerintahan yang terkait. Kolaborasi membangun Purwakarta antara pemerintah dan sektor perusahaan merupakan sebagai bagian dari program amanat Undang-undang Peseroan Terbatas yang mewajibkan setiap perusahaan untuk dapat berkontribusi dalam pembangunan di wilayahnya dalam bentuk program kemitraan dan bina lingkungn (PKBL) untuk Badan Usaha Milik Negara (BUMN) dan Corporate Social Responsibility (CSR) untuk perusahaan swasta.

Selain dalam rangka memenuhi kewajiban sebagai perusahaan terhadap lingkungan sekitranya, ternyata tujuan lain perusahaan memberikan bantuan dalam membantu pembangunan di suatu daerah ialah untuk mempertahankan dan mengembangkan citra, reputasi dan aset penjualan dari produk atau jasa perusahaan dalam bentuk marketing public relations (MPR). Karena dalam konsep MPR bagi suatu perusahaan yaitu selain dapat menjual produk, tercapai juga citra dan reputasi dari produk dan perusahaannya di masyarakat. Dengan terlibatnya suatu perusahaan dalam proses pembangunan yang berwawasan budaya akan semakin memperkuat positioning sebagai perusahaan yang peduli terhadap pelestarian budaya di Purwakarta. Menurut Trout (2002:56) positoning bukanlah apa yang dilakukan terhadap produk, melainkan apa yang dilakukan terhadap benak (pikiran) yang ada di khalayak (Razali \& Lubis, 2017).

Peranan stakeholders yang ketiga dari Triple Helix pada proses pembangunan Purwakarta yaitu masyarakat. Keberadaan masyarakat dalam proses pembangunan menjadi sangat penting. Karena peranan masyarakat sebagai subjek dan objek pembangungan, maka keberadaannya harus dilibatkan dalam 
rangka menjaga, memelihara, melaksanakan dan mengawasi proses pembangunan beserta capaiannya.

Di Purwakarta sendiri, masyarakat ikut terlibat dalam proses pembangunan dengan sangat antusias. Hal ini dapat terlihat dari setiap kegiatan yang diselenggarakan oleh pemerintah dalam bentuk acara festival, event pembangunan dan gempungan, masyarakat selalu hadir untuk menyampaikan aspirasi dan mendapatkan pelayanan "istimewa" dari pemerintah kabupaten.

Dalam gambar 3, dapat diterangkan bahwa tingkat partisipasi masyarakat dalam pembangunan di Purwakarta sangat mendukung. Bentuk dukungan yang ditunjukkan oleh masyarakat terhadap terwujudnya Purwakarta Berkarakter dan Istimewa yaitu programprogram yang diusulkan oleh pemerintah

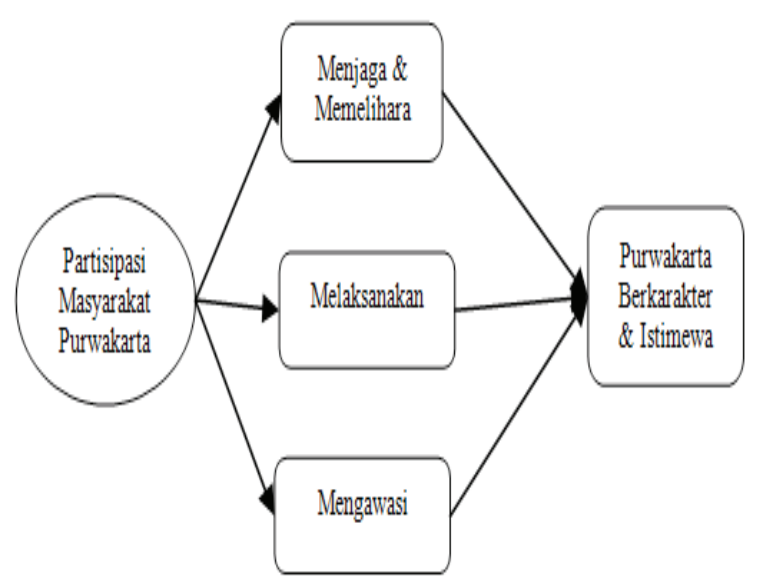

Sumber: Hasil Penelitian, 2018

Gambar 3 Peran Masyarakat dalam Pembangunan Purwakarta Berkarakter dan Istimewa kabupaten yang diimplementasikan oleh SKPD selalu menjadi perhatian dan diikuti dengan baik. Selain itu, partisipasi masyarakat Purwakarta sangat antusias apalagi terkait dengan pemenuhan atas hak dasar layanan publik dari pemerintah yang tadinya sulit sekarang mudah didapatkan dengan adanya keterbukaan dan pemanfaatan teknologi yang berbasis pada kebutuhan masyarakat.

Bentuk partisipasi masyarakat di acara "Gempungan" sangat dinanti-nantikan karena disitulah merupakan tempat untuk menyampaikan aspirasi dari bawah kepada pemerintah dan sebagai wahana pemenuhan kebutuhan dasar layanan publik yang sangat praktis dari pemerintahan kabupaten Purwakarta. Sebagaimana hal ini diperkuat dari hasil penelitian Herladianti et al., (2016) yang menyebutkan secara umum kegiatan Gempungan merupakan bentuk pelayanan pemerintah kepada masyarakat yang bersifat "jemput bola", berupa pelayanan administrasi kependudukan(KTP, KK, Akte Kelahiran, Buku Nikah dan lainnya), pelayanan kesehatan, donor darah, pelayanan $\mathrm{KB}$, khitanan massal, serta masukan dari tokoh agama, tokoh masyarakat serta warga secara keseluruhan yang dilakukan seminggu sekali berputar di 192 desa dan kelurahan di wilayah kabupaten Purwakarta.

Adanya partisipasi masyarakat yang antusias menandakan bahwa masyarakat 
cenderung mendukung program-program pembangunan Purwakarta Berkarakter \& Istimewa yang digulirkan oleh pemerintah kabupaten agar menjadi daerah yang memiliki identitas yang baik sebagai daerah yang mengimplementasikan pemenuhan terhadap layanan publik yang cepat, sederhana, dan humanis. Yang pada akhirnya, wilayah Purwakarta sekarang berbeda dengan dulu, yang dimana kawasan kota yang tertata dan kampung yang terurus. Terkelolanya pembangunan di Purwakarta yang menganut modernitas dengan kembali ke masa lalu tepatnya memelihara dan mengangkat nilai-nilai yang tertanam dalam basis budaya Sunda menghasilkan suatu penghargaan dan pujian dari berbagai kalangan. Sebagai kota yang berkarakater, Purwakarta sekarang dapat dikategorikan modern dengan tetap menghargai dan menegakkan unsur-unsur yang kokoh akar budanya Sunda dalam sistem pemerintahan, pelayanan masyarakat, dan pembangunan.

Upaya mencapai tujuan pembangunan yang berlandaskan nilai lokalitas di wilayah Purwakarta dibutuhkan keterlibatan semua pihak. Dengan kata lain, peran berbagai publik (stakeholders) dalam pola pembangungan berkarakter dan berkelanjutan menjadi sangat penting untuk dikelola dengan baik. Stakeholders atau publik adalah sekelompok orang dalam masyarakat yang sifatnya homogen yang memiliki minat, perhatian dan kepentingan yang sama terhadap suatu hal (Yulianita, 2007: 17).

Berdasarkan hasil diskusi dengan perangkat pemerintahan yang memiliki kepentingan dengan program pembangunan Purwakarta Berkarakter dapat dikategorisasikan menjadi masyarakat, lembaga keagamaan, lembaga swadaya masyarakat, investor, dan dinasdinas pemerintahan. Kesemua stakeholders yang terlibat dalam pembangunan Purwakarta Berkarakter \& Istimewa memiliki perannya masing-masing sesuai dengan kemampuan. Dan secara umum peran stakeholders tersebut adalah ada yang berperan pada pembangunan sistem pemerintahan dan reformasi birokrasi, keefektifan pelayanan publik, membangun destinasiwisata, ekonomi kreatifdan kerakyatan, serta pendidikan, kehidupan beragama dan kesehatan yang berkualitas. Terkait dengan peran pemerintah dalam mengembangkan kemajuan pembangunan daerah secara garis besarnya adalah menyediakan infrastruktur, memperluas berbagai bentuk fasilitas program pembangunan, penyediaan kebijakan pelaksanaan pembangunan, serta melaksanakan sistem evaluasi yang berkelanjutan.

Dari gambar 4 dapat dijelaskan bahwa lahirnya identitas daerah Purwakarta sebagai kota sejuta impian dan menjadi kota destinasi wisata budaya yang terbangun sekarang ini 


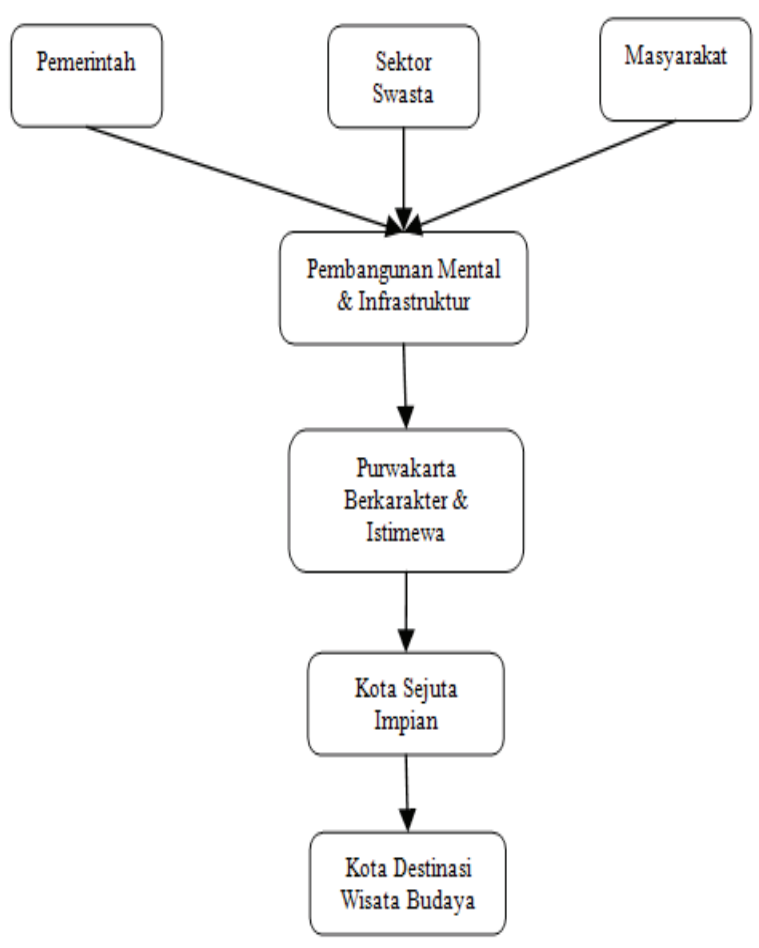

Sumber: Hasil Penelitian, 2018

\section{Gambar 4 Kolaborasi Triple Helix dalam Upaya Mewujudkan Identitas Kabupaten Purwakarta}

merupakan hasil dari kontribusi berbagai stakeholders yang secara hasil dapat terlihat dari pembangunan infrastruktur di kota Purwakarta. Beberapa bentuk pembangunan infrastruktur Purwakarta merupakan bentuk representasi dari nilai-nilai budaya Sunda dengan menyematkan nama-nama taman kota yang menggunakan dan bernuansakan filosofi Sunda serta pelaksanaan program dasar layanan publik pada sektor pendidikan, kesehatan, kesejahteraan sosial dan lainnya. Adapun contoh dari hasil pembangunan infrastruktur yang ditonjolkan dari sisi nilai budaya Sunda yaitu bentuk gerbang memasuki kota Purwakarta dan beberapa taman yang

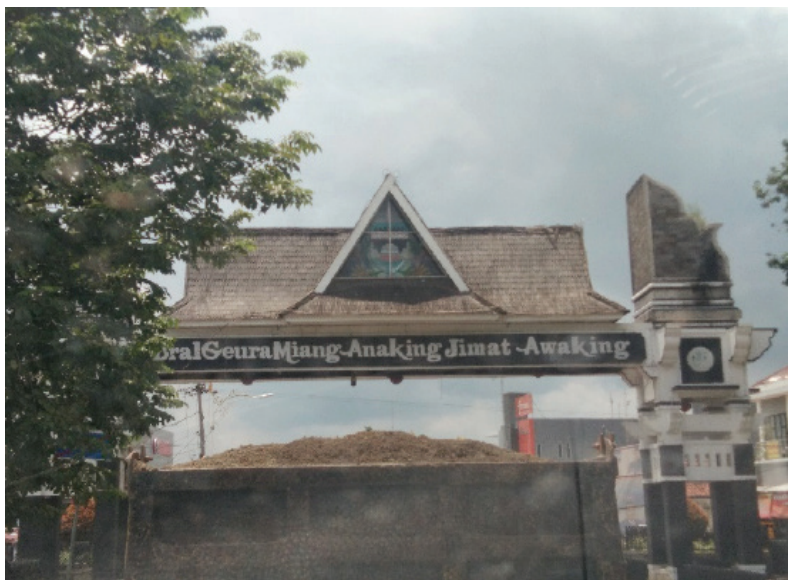

Sumber: Dokumentasi Penelitian, 2018

Gambar 5 Gerbang Indung Rahayu Sebagai
Identitas Masuk Kota Purwakarta

tematik berdasarkan filosofi Sunda.

Gambar 5 menunjukkan bahwa tampilan gerbang masuk kota Purwakarta berupa atap Julang Ngapak, motif pucuk bunga Melati, dan berisikan tulisan pepatah Sunda. Dari dua identitas yang mengandung arti bahwa Julang Ngapak berarti melambangkan perlindungan dan mengayomi seluruh warga kabupaten Purwakarta. Untuk motif bunga melati diartikan sebagai kesucian dan keharuman bagi wilayah Purwakarta. Dan pepatah Sunda tersebut diartikan sebagai doa seorang indung (pemerintah) untuk warga masyarakatnya agar mendapatkan kebaikan (kemakmuran).

Gambar 6 menunjukkan bahwa kota Purwakarta sebagai kota destinasi wisata budaya dapat terwujud berkat pembangunan yang didukung oleh berbagai pihak. Terwujudnya pembangunan yang berwawasan budaya tidak terlepas inisiator ide cemerlang sang Bupati 


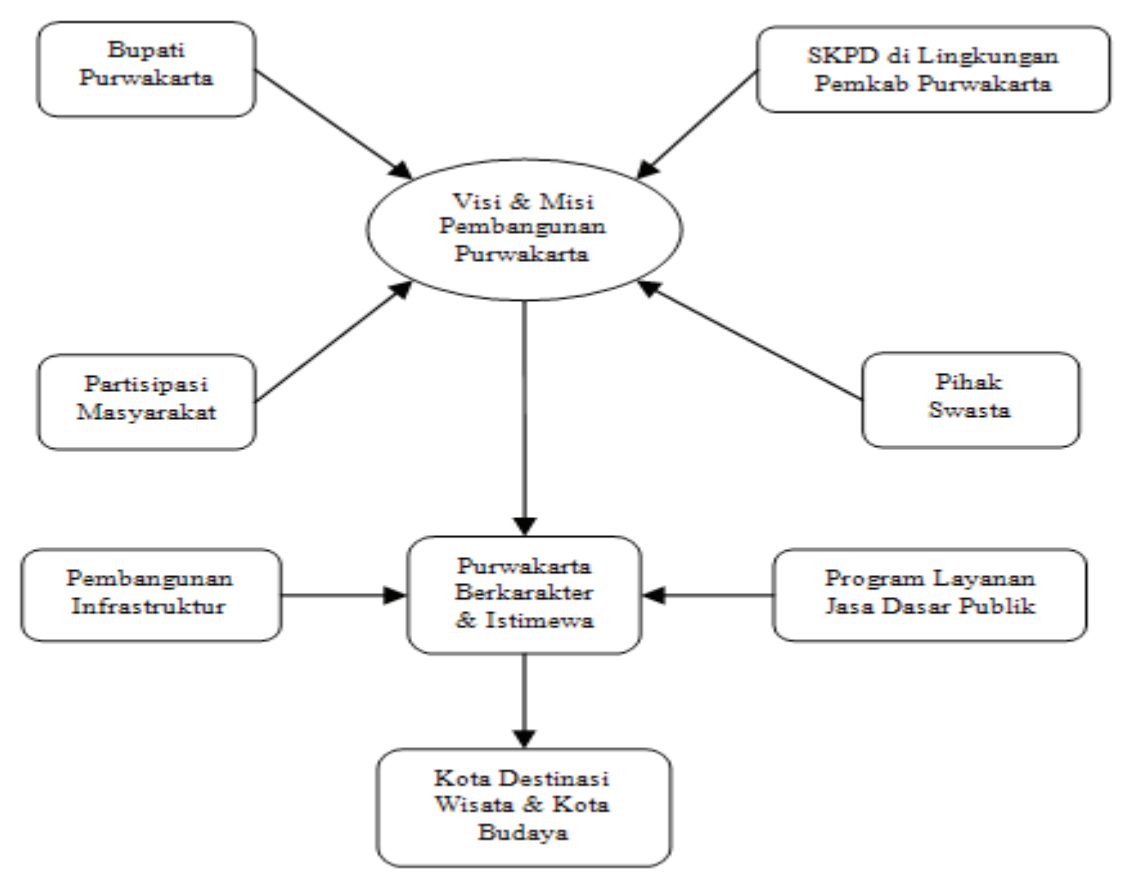

Sumber: Hasil Penelitian, 2018

\section{Gambar 6 Kolaborasi Stakeholders dalam Mewujudkan Identitas Kabupaten Purwakarta}

Dedi Mulyadi yang diterjemahkan pada visi dan misi pembangunan Purwakarta untuk dapat menjadi kota yang "hidup" dari segala sektor pembangunan terutama dalam hal memajukan pariwisata kabupaten Purwakarta.

Untuk gambar 7 yang menunjukkan sosialisasi kabupaten Purwakarta sebagai kota destinasi wisata budaya di Jawa Barat menggunakan berbagi media komunikasi. Salah satu media komunikasi yang digunakan adalah mobil tangki air milik PDAM Kabupaten Purwakarta yang memiliki logo Purwakarta Istimewa. Logo identitas sebagai kota destinasi wisata budaya tidak jauh berbeda maknanya terkait dengan filosofi kesundaan yang terdapat pada bangunan, taman, dan pilar dari kantorkantor lembaga pemerintahan kabupaten

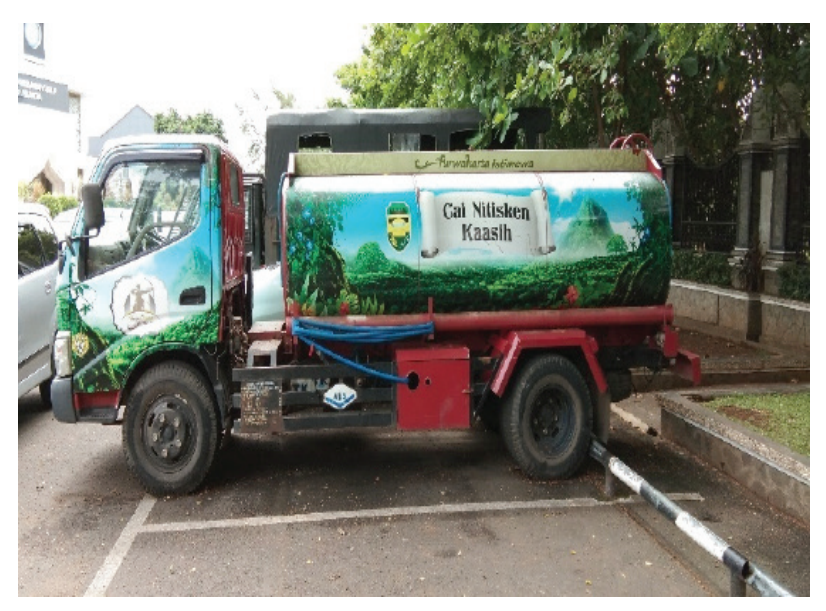

Sumber: Dokumentasi Penelitian, 2018

\section{Gambar 7 Logo Identitas Purwakarta Istimewa pada Moda Transportasi Layanan Publik Milik Pemerintah Kabupaten}

Purwakarta. Dengan kehadiran nilai budaya Sunda pada elemen pembangunan infrastruktur dan mental di Purwakarta bukan berarti menunjukkan bahwa Purwakarta kembali ke masa peradaban Sunda dulu, melainkan dalam 
upaya menyelamatkan dan meningkatkan peradaban modern yang dipadukan antara budaya dan agama dan tetap yang mewujudkan tampilan sebagai kota modern.

\section{SIMPULAN}

Kabupaten Purwakarta memiliki identitas sebagai kota destinasi wisata budaya di Jawa Barat merupakan sebuah identitas dari hasil perjuangan pemerintahan kabupaten Purwakarta yang didukung oleh pihak swasta dan masyarakat dalam membangun tata kota dan desa wilayah Purwakarta secara baik dan profesional. Sehingga keberadaan tata kelola pemerintahan, pelayanan publik dan proses pembangunan mental dan infrastruktur di Purwakarta identik dengan unsur filosofi budaya Sunda yang dicetuskan oleh Bupati Dedi Mulyadi dengan slogan wilayah perkotaan ditata, wilayah pedesaan diurus.

\section{DAFTAR PUSTAKA}

Adrian, J., \& Maharani, N. (2018). Keberlangsungan Good News From IndonesiaSebagai Pelaku Jurnalisme Alternatif. Kajian Jurnalisme, 1(2), 107123.

Ainun, S., \& Nugroho, C. (2019). Unsur budaya dalam media sosial: studi pada facebook kang dedi mulyadi. Manajemen Komunikasi, 3(2), 158-172.

Aiysiyah, P., \& Dewi, R. (2011). Konstruksi Identitas Kedaerahan oleh Media Massa
Lokal. Jurnal Komunikasi, 1(2), 149-158.

Barata, I. G., Dektisa, A., \& Arini, B. D. (2015). Perancangan destination branding wisata alam kabupaten Karanganyar Jawa Tengah. Jurnal DKV Adiwarna, 1(6), 1-11.

BPS. (2018). Umur Harapan Hidup saat Lahir (UHH) Provinsi Jawa Barat 2010-2017.

Detik.com. (2019). Vivo V15 Mau Launching di Purwakarta, Berikut Fakta Menariknya. Djaenuri, A. (2015). Kepemimpinan, etika \& kebijakan pemerintahan. Bogor: Ghalia Indonesia.

Evadianti, Y. (2017). Reposisi brand dalam festival Krakatau oleh dinas kebudayaan dan pariwisata provinsi Lampung. Jurnal PRofesi Humas, 2(1), 23-36.

Gifari, F., \& Purnama, H. (2017). Strategi AsiaPR dalam memperkuat hubungan media dengan forum wartawan otomotif (Forwot). Jurnal Profesi Humas, 1(2), 101-111.

Hariyanto, O. I. B. (2017). Membangun karakter sadar wisata masyarakat di destinasi melalui kearifan lokal Sunda. Jurnal Pariwisata, IV (1), 32-39.

Herladianti, A., Damayanti, T., \& Prastowo, F. A. A. (2016). Pencitraan Bupati Purwakarta melalui kegiatan gempungan di kabupaten Purwakarta. Jurnal Edutech, 15(2), 112137.

HumasCNN. (2017). Perum Jasa Tirta II Dukung Program CSR-PKBL Jabar.

Kompasiana. (2017). CSR Hino Indonesia unik dan menarik.

Luqman, Y., Sumardjo, Sarwoprasodjo, S., \& Tambunan, A. H. (2017). Solusi menuju konvergensi arah komunikasi kebijakan publik dalam rangka antisipasi krisis energi. Jurnal Ilmu Komunikasi, 15(2), 134-145.

Moleong, L. J. (2000). Metode penelitian kualitatif. Bandung: PT. Remaja Rosda 
Karya.

Mulyadi, D. (2012). Pembangunan berkarakter.

(A. Gunawan, Ed.). Purwakarta: Badan

Perencanaan dan Pembangunan Daerah Kabupaten Purwakarta.

Mulyana, D. (2001). Merancanag peran baru Humas dalam pengembangan otonomi daerah. Jurnal MediaTor, 1(1), 1-9.

Pratiwi, S. R., Dida, S., \& Sjafirah, N. A. (2018). Strategi komunikasi dalam membangun awareness wisata halal di kota Bandung. Jurnal Kajian Komunikasi, 6(1), 78-90.

Putri, N. E., Hakim, N., \& Yamin, M. (2016). Ecologicall Footprint and Biocapacity Analysis for Flooding Prevention in South Sumatera. Jurnal Mimbar, 32(1), 58-64.

Razali, G., \& Lubis, E. E. (2017). Strategi positioning radio Mandiri 98,3 Fm sebagai radio news and business Pekanbaru. Jurnal
Komunikasi, VIII(3), 267-274.

Razi, F. (2011). NU dan kontinuitas dakwah kultural. Jurnal Komunikasi Islam, 01(2), 161-171.

Sedarmayanti. (2018). Komunikasi Pemerintahan. Bandung: Refika Aditama.

Susilo, M. E., Prayudi, \& Erawati, H. (2016). Pendekatan stakeholders engagement dalam pengembanan desa wisata. Jurnal Ilmu Komunikasi, 14(2), 122-135.

Susilo, N. S. (2013). Identity management primary relationship berbudaya Jawa dan Toraja. Jurnal E-Komunikasi, 1(1), 1-12.

Wulandari, T. (2013). Analisis Place Branding untuk Meningkatkan Citra Kabupaten Purwakarta serta Implikasinya terhadap Keputusan Mengunjungi Destinasi Pariwisata. Jurnal Ilmu Manajemen \& Bisnis, 04(01), 1-12. 